\title{
THE CREATIVITY OF FUTURE ENGINEERS, AN INSUFFICIENTLY EXPLOITED RESOURCE IN ROMANIAN ORGANIZATIONS
}

\author{
MORARU Gina-Maria ${ }^{1}$ \\ 1"Lucian Blaga" University of Sibiu, Faculty of Engineering, Sibiu, Romania, gina.moraru@ulbsibiu.ro
}

\begin{abstract}
The main purpose of the paper is to warn the academic environment that neither Romanian universities, nor Romanian business organizations, nor public or social ones sufficiently capitalize on students' creativity. To begin with, we have presented some links that should be built at the society level between certain notions of creativity management and the goals of sustainable global development. In essence, any step taken by modern organizations towards sustainable development, starting with the development of a recyclable product and ending with the development and implementation of an innovative strategy, involves the maximum use of this inexhaustible resource, which is human creativity and is more pronounced among young people. After this bibliographic study, we have presented the results of a research from secondary sources carried out at the Faculty of Engineering of the "Lucian Blaga" University of Sibiu. We have analysed the team projects made by the students of the final years from the Mechatronics and Economic Engineering in the Mechanical Field specializations to those economic subjects that sought, among other things, to develop their creativity. The research was conducted over the last two academic years. We mention that most of the students had a job, and several of their projects used data from the companies in which they were employed. Although they had the consent of management for using and processing of data, too few organizations showed interest in the results of their scholar research. Whether or not the projects used company data, a very small number of students said that the management of the organization in which they work would be interested in their projects. Our main recommendation is to find ways to bring engineering faculties closer to organizations in the field of production and services.
\end{abstract}

KEY WORDS: Creativity, sustainable, development, mechatronics, engineering

\section{INTRODUCTION}

"Creativity and sustainability are two important features for mankind, with creativity considered as a self-actualizing process, fulfilling human basic needs." [1] With the opening of the innovation process to society, citizens and customers join companies, universities and research institutes in the process of solving problems and developing new products [2]. In this context, the concept of sustainable creativity emerged [3]. In essence, any step taken by modern organizations towards sustainable development, starting with the development of a recyclable product and ending with the development and implementation of an innovative strategy, involves the maximum use of this inexhaustible resource, which is human creativity and is more pronounced among young people.

"The initiatives to encourage the creativity of a younger generation at the EU level [...] should be accompanied by evident efforts at a country's and company's level" [4]. But in the Romanian context, students' creativity remains largely untapped. Unfortunately, many teachers in Romania are not very sure of the importance of students' creativity in the curriculum (see [5], Graph 19, p. 52). Moreover, educational culture in many European countries is not yet supporting teachers in fostering students' creativity [5]. Therefore, the main purpose of this paper is to warn the academic environment that neither Romanian universities, nor Romanian business organizations, nor public or social ones sufficiently capitalize on students' creativity.

\section{BIBLIOGRAPHIC STUDY}

In order to discover some links that should be built at the societal level between certain notions of creativity management and the objectives of sustainable global development, we considered it appropriate to study these relationships, present in the literature, on the three levels of creativity found in any organization or economic structure: individual, group and organizational level (Figure 1).

At the individual level, from the perspective of the pressure exerted on the employee to bring added value to the company through creativity, the specialists showed that "creativity can be linked not only to environmental and economic sustainability but also to the dimensions of social and human sustainability" [6]. But, in order to manage properly individual creativity, leaders must take into account the risks due to the possible occurrence of negative creativity, which can destroy the organization [7].

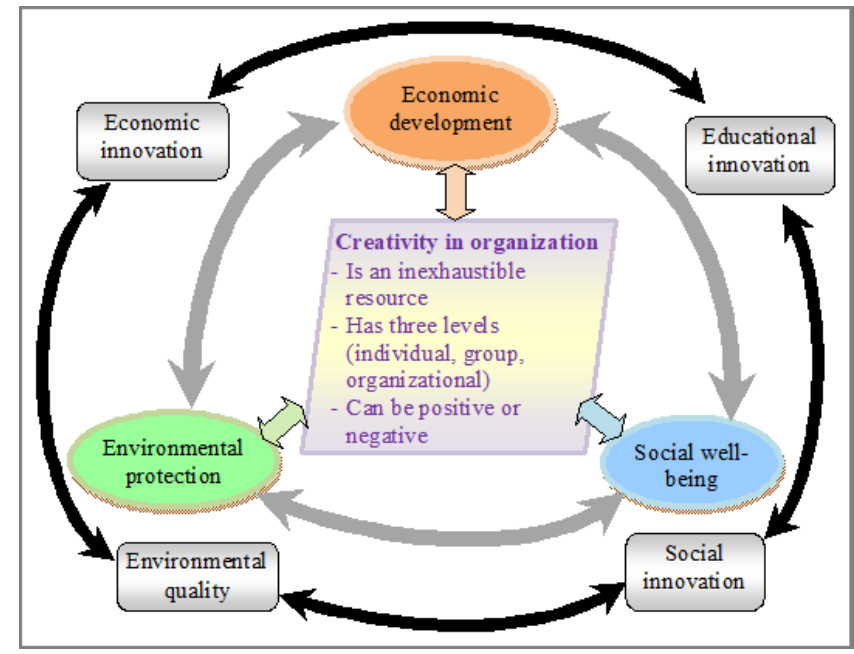

Figure 1. Framework and findings of the bibliographic study about the relation between certain notions of creativity management and the goals of sustainable global development (source: the author). 
Approaching group creativity as a potential engine of knowledge creation, the specialists showed that group creativity studies focused on three main directions: group creativity in context, creative synergy at group level and strategies for developing group creativity [8]. Studies on group creativity, from the perspective of its approach, can be divided into two main categories: predominantly quantitative studies and qualitative studies [8].

Turning to the level of organizational creativity, specialists have noticed for almost a decade its connection with sustainability: "a sustainable business is impossible without the creativity, because creativity is not just paintings or other arts, creativity is the generation of new ideas, talents, skills, underlying new achievements, technologies" and so on [4]. Business-level innovation, in line with the three dimensions of sustainability, does not yet have a rule, as the inclusion of the social and environmental dimensions alongside the economic one requires new management tools and models, which have only recently begun to be developed more intensively [9]. This is not only a task for companies intending to innovate, but also education and research institutions, government agencies, standardization institutions, civil society organizations, namely the whole national innovation system, play an important role in this matter [9].

Over the last decade, recognized sources of innovation in society have begun to include civil society in their actions [10]. Thus, civil society has been added as the fourth source of innovation that makes up the "quadruple spiral" and this has happened at the same time as the concept of social innovation has come to the fore in both academic discourse and the politics of developed countries [10].

Related to the integration of creativity and sustainability at the educational level, specialists found that an education in the spirit of creativity and entrepreneurship can lead to student success only if we give up the "national-silo" notion that seeks primarily innovation and creativity to establish a competitive economic advantage of one nation over another [11]. Our young entrepreneurs should learn how their well-being is related to the well-being of other people and the planet, and then they can be inspired to apply their entrepreneurial mindset to create positive changes - maybe even a change in education [11].

\section{RESEARCH FROM SECONDARY SOURCES}

In order to prove the considerations above, we have carried out a research from secondary sources at the Faculty of Engineering of the "Lucian Blaga" University of Sibiu. The Faculty of Engineering developed, during the studied period, fifteen engineering specializations. We chose for our research only two of the specializations, based on two considerations. The first consideration was that in the last year of study to be taught important socio-economic subjects, which develop entrepreneurial skills, the adaptability of future engineers to the business environment, but also their creativity. The second consideration was that, for the respective disciplines, the teacher has also provided for the realization of team projects, whose share in the final grade should be at least $40 \%$.

\subsection{Methodology and Premises}

The methodology consisted in the analysis of the projects realized by the students of the final years from the Mechatronics and Economic Engineering in the Mechanical Field specializations to those economic subjects that sought, among other things, to develop their creativity. The research was conducted over the last two academic years. The subjects taught for which the project analysis was performed were: Organizational Theory and Behaviour, for Economic Engineering in the Mechanical Field specialization, and respectively Management and Marketing, for Mechatronics specialization.

We mention that most of the students had a job, and several of their projects used data from the companies in which they were employed. Although they had the consent of management for using and processing of data, too few organizations showed interest in the results of their scholar research. Whether or not the projects used company data, a very small number of students said that the management of the organization in which they work would be interested in their projects. (We asked them this question when presenting the project.)

\subsection{The Most Important Results for Economic Engineering in the Mechanical Field Specialization}

The students in the 4th year from the Economic Engineering in the Mechanical Field specialization have developed 40 projects for the subject "Organizational Theory and Behaviour" during the last two academic years (see Table 1). We mention that, at the beginning of the semester, taking into account the students preferences, a balanced distribution of the topics was followed:

$1 / 3$ projects for companies;

$1 / 3$ projects for the academic field;

$1 / 3$ projects for the general topic or for nonprofit organizations.

Regarding the projects carried out in companies (Table 1), figure 2 shows at different positions the projects for which the management of the companies showed interest and the projects that did not show interest for managers.

Unfortunately, projects carried out in companies that did not show interest for managers have the lowest share in figure 2 . It is clear that neither the creativity nor the work of future engineers is appreciated at its true value by the management of companies in Sibiu, Romania.

Table 1. Centralized data related to Economic Engineering in the Mechanical Field students' projects (source: the author).

\begin{tabular}{|c|c|c|c|c|c|c|c|}
\hline $\begin{array}{c}\text { Academic } \\
\text { year }\end{array}$ & $\begin{array}{l}\text { Number } \\
\text { of } \\
\text { students } \\
\text { involved } \\
\text { in team } \\
\text { project }\end{array}$ & $\begin{array}{c}\text { Total } \\
\text { number } \\
\text { of } \\
\text { projects }\end{array}$ & $\begin{array}{l}\text { Projects } \\
\text { with } \\
\text { potential } \\
\text { interest } \\
\text { for } \\
\text { ULBS }\end{array}$ & $\begin{array}{c}\text { General } \\
\text { projects or } \\
\text { projects } \\
\text { developed in } \\
\text { nonprofit } \\
\text { organizations* }\end{array}$ & $\begin{array}{c}\text { Number of } \\
\text { projects carried } \\
\text { out in companies } \\
\text { (based on primary } \\
\text { and/or secondary } \\
\text { research sources) }\end{array}$ & $\begin{array}{c}\text { Number of } \\
\text { companies studied } \\
\text { in a single project } \\
\text { (from projects } \\
\text { carried out in } \\
\text { companies) }\end{array}$ & $\begin{array}{c}\text { Number of } \\
\text { companies studied } \\
\text { in } 2 \text { or } 3 \text { projects } \\
\text { (from projects } \\
\text { carried out in } \\
\text { companies) }\end{array}$ \\
\hline $2018-2019$ & 49 & 22 & 7 & 8 & 7 & 8 & 1 \\
\hline $2019-2020$ & 52 & 18 & 7 & 5 & 6 & 8 & 1 \\
\hline
\end{tabular}




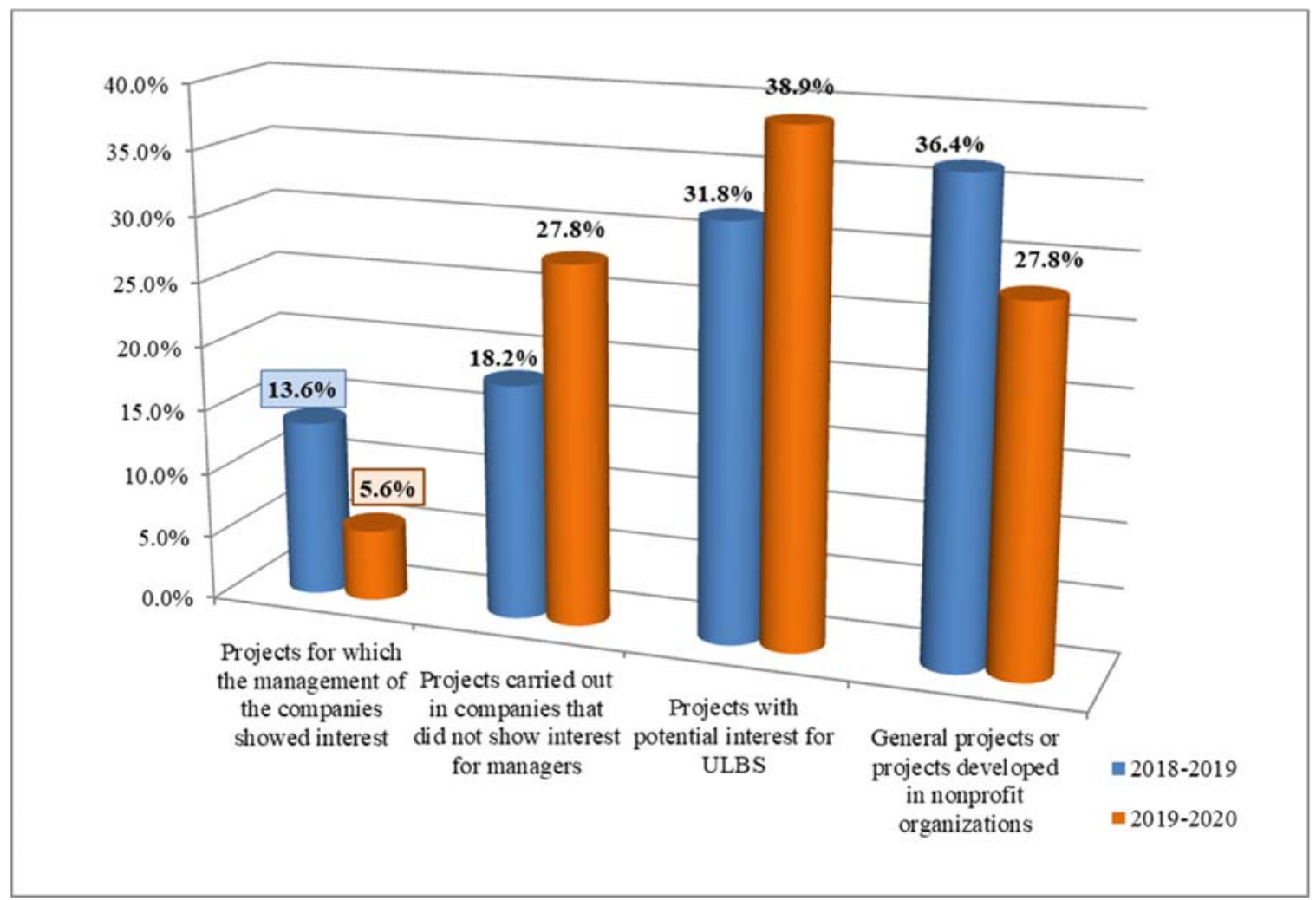

Figure 2. Classification of projects from the discipline of Organizational Theory and Behaviour according to how they can be used (source: the author).

To exemplify we have presented in table 2 a more detailed situation of the team projects for Organizational Theory and

Behaviour that did not interest companies' managers in 2019 (4 of the total of 7 projects carried out in companies).

Table 2. Projects of the students in Economic Engineering in the Mechanical Field that did not interest companies' managers in 2019 (source: the author).

\begin{tabular}{|c|l|c|c|c|}
\hline Number & \multicolumn{1}{|c|}{ Team project title } & $\begin{array}{c}\text { Sources } \\
\text { of the } \\
\text { research }\end{array}$ & $\begin{array}{c}\text { The number of } \\
\text { companies analyzed } \\
\text { in the project }\end{array}$ & $\begin{array}{c}\text { The reason for not using the } \\
\text { results of the project }\end{array}$ \\
\hline 1 & $\begin{array}{l}\text { The perception of research and development } \\
\text { engineers versus the perception of production } \\
\text { engineers in automotive companies }\end{array}$ & Primary & 2 & $\begin{array}{c}\text { Managers said the topic was of } \\
\text { no interest. }\end{array}$ \\
\hline 2 & Employee opinion on entrepreneurship & Primary & 2 & $\begin{array}{c}\text { Managers said the topic was of } \\
\text { no interest. }\end{array}$ \\
\hline 3 & Employees' attitude towards work & Primary & 1 & $\begin{array}{c}\text { Managers said similar research } \\
\text { has been done in the past. }\end{array}$ \\
\hline 4 & $\begin{array}{l}\text { Comparative analysis of pharmaceutical industry } \\
\text { organizations }\end{array}$ & Secondary & 3 & $\begin{array}{c}\text { No contact was made with the } \\
\text { companies. }\end{array}$ \\
\hline
\end{tabular}

\subsection{The Most Important Results for Mechatronics Specialization}

The students in the 4th year from the Mechatronics specialization have developed 15 projects for the subject "Management and Marketing" in the last two academic years
(Table 3). The number of projects in this specialization was lower than in Economic Engineering in the Mechanical Field specialization (Table 1), because, on the one hand, the number of students was smaller, and on the other hand, one of the three subgroups was not involved in team projects (in order to carry out another research).

Table 3. Centralized data related to Mechatronics students' projects (source: the author).

\begin{tabular}{|c|c|c|c|c|c|c|c|c|}
\hline $\begin{array}{c}\text { Academic } \\
\text { year }\end{array}$ & $\begin{array}{c}\text { Total } \\
\text { number } \\
\text { of } \\
\text { students }\end{array}$ & $\begin{array}{c}\text { Number of } \\
\text { students } \\
\text { who } \\
\text { prepared } \\
\text { individual } \\
\text { portfolios (a } \\
\text { subgroup) } \\
\end{array}$ & $\begin{array}{c}\text { Number of } \\
\text { students } \\
\text { involved in } \\
\text { team } \\
\text { projects } \\
\text { (two } \\
\text { subgroups) } \\
\end{array}$ & $\begin{array}{c}\text { Number } \\
\text { of } \\
\text { projects }\end{array}$ & $\begin{array}{l}\text { Projects for } \\
\text { which the } \\
\text { management } \\
\text { of the } \\
\text { companies } \\
\text { showed } \\
\text { interest } \\
\end{array}$ & $\begin{array}{c}\text { Projects } \\
\text { that did } \\
\text { not } \\
\text { interest } \\
\text { companies' } \\
\text { managers }\end{array}$ & $\begin{array}{l}\text { Projects } \\
\text { with } \\
\text { potential } \\
\text { interest } \\
\text { for } \\
\text { ULBS }\end{array}$ & $\begin{array}{c}\text { General } \\
\text { projects or } \\
\text { projects } \\
\text { developed in } \\
\text { nonprofit } \\
\text { organizations }\end{array}$ \\
\hline $2018-2019$ & 42 & 15 & 27 & 8 & 2 & 3 & 3 & 0 \\
\hline $2019-2020$ & 35 & 35 & 22 & 7 & 0 & 3 & 1 & $3 *$ \\
\hline
\end{tabular}


We do not deny that for the realization of certain student projects obtaining the agreement from companies for the use of data is a problem. But, after getting this agreement and after the substantial work of the students for the project development, the implementation of the results of many projects is practically impossible in most companies.
In the subject of Management and marketing, students were encouraged in the first hour of applications to choose project themes that they are passionate about. Perhaps this was also a cause of the lack of attractiveness of the themes for managers (Table 4).

Table 4. Projects of the students in Mechatronics that did not interest companies' managers in the last two academic years (source: the author).

\begin{tabular}{|c|c|c|c|c|c|}
\hline Number & Team project title & $\begin{array}{l}\text { Academic } \\
\text { year }\end{array}$ & $\begin{array}{l}\text { Sources } \\
\text { of the } \\
\text { research }\end{array}$ & $\begin{array}{c}\text { The number of } \\
\text { companies analyzed } \\
\text { in the project }\end{array}$ & $\begin{array}{l}\text { The reason for not using the } \\
\text { results of the project }\end{array}$ \\
\hline 1 & $\begin{array}{l}\text { Proposal to launch in production at } \\
\text { company " } \mathrm{X} \text { " a new mechatronic } \\
\text { system, from } 3 \text { proposed systems }\end{array}$ & $\begin{array}{l}2018- \\
2019\end{array}$ & Primary & 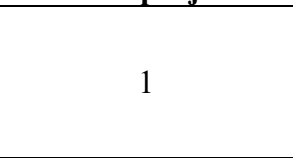 & $\begin{array}{l}\text { Managers said that the launch of } \\
\text { the new products is not done in } \\
\text { Sibiu, but at the parent } \\
\text { company. }\end{array}$ \\
\hline 2 & $\begin{array}{l}\text { Management tools proposed for } \\
\text { streamlining some activities in } \\
\text { company "Y" }\end{array}$ & $\begin{array}{l}2018- \\
2019\end{array}$ & Primary & 1 & $\begin{array}{l}\text { Managers said the topic was of } \\
\text { no interest. }\end{array}$ \\
\hline 3 & $\begin{array}{l}\text { Buying and selling } 2 \text {-stroke engine } \\
\text { oils on the Romanian market }\end{array}$ & $\begin{array}{l}2018- \\
2019\end{array}$ & Secondary & 3 & $\begin{array}{l}\text { No contact was made with the } \\
\text { companies. }\end{array}$ \\
\hline 4 & $\begin{array}{l}\text { The role of virtual simulation in } \\
\text { providing secure products to the } \\
\text { customer }\end{array}$ & $\begin{array}{l}2019- \\
2020\end{array}$ & Primary & 1 & $\begin{array}{l}\text { Managers said similar research } \\
\text { has been done in the past. }\end{array}$ \\
\hline 5 & $\begin{array}{l}\text { Intelligent systems for lighting } \\
\text { rooms }\end{array}$ & $\begin{array}{l}2019- \\
2020\end{array}$ & $\begin{array}{l}\text { Primary } \\
\text { and } \\
\text { secondary }\end{array}$ & 1 & $\begin{array}{l}\text { Managers said similar research } \\
\text { has been done in the past. }\end{array}$ \\
\hline 6 & $\begin{array}{l}\text { Car repair between passion and } \\
\text { business }\end{array}$ & $\begin{array}{l}2019- \\
2020\end{array}$ & $\begin{array}{l}\text { Primary } \\
\text { and } \\
\text { secondary }\end{array}$ & 1 & $\begin{array}{l}\text { Managers said the topic was of } \\
\text { no interest. }\end{array}$ \\
\hline
\end{tabular}

The results obtained in the two engineering specializations determine us to state that Romanian engineering faculties must focus on the relations with industrial groups and SMEs. We tried to highlight this by framing in red these categories of stakeholders on a scheme already published in the literature, which presents the university as a system of excellence (Figure 3).

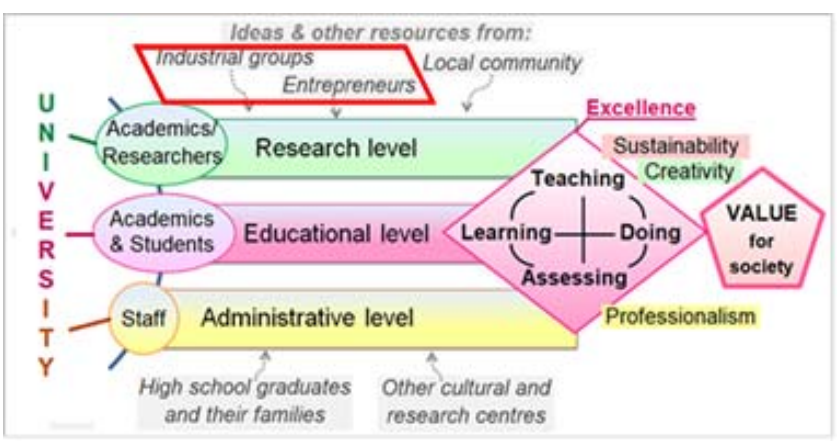

Figure 3. A university that integrates ideas into a system of excellence (source: [12], p. 4407).

\section{REFERENCES}

1. D'Orville, H. (2019) The Relantionship between Sustainability and Creativity. Cadmus Journal, 4(1), 6573. Retrieved

from https:/cadmusjournal.org/files/pdfreprints/vol4issue1/TheRelationship-between-Sustainability-and-CreativityHd'orville-Cadmus-V4-I1-Reprint.pdf, last accessed 2020/11/09.

\section{CONCLUSIONS}

Even if the study is limited only to the Faculty of Engineering of the "Lucian Blaga" University of Sibiu, we do not expect that in other industrial areas of Romania the situation of capitalizing on the creativity of future engineers will be better. Although the authors of the projects had the consent of the management of the companies for data collection and processing, in too few cases their scientific research attracted the attention of middle and operational managers.

Our main recommendation is to find ways to bring engineering faculties closer to organizations in the field of production and services. It is necessary to make the online working environment of the academic environment more flexible with the business environment. With online teaching, the effective involvement of operational managers in projects in different disciplines can be just a click away, provided that the working procedures in the university allow it. The initiative, as well as the promotion of this way of cooperation, should come from the academic environment, because the representatives of the business environment are now much too bothered by the COVID-19 crisis and the problems generated by it.

2. Howaldt, J., Butzin, A., Domanski, D., \& Kaletka, C. (2014) Theoretical Approaches to Social Innovation - A Critical Literature Review. A deliverable of the project: "Social Innovation: Driving Force of Social Change" (SIDRIVE). Dortmund: Sozialforschungsstelle. Retrieved from http://www.si-drive.eu/wpcontent/uploads/2014/11/D1_1-Critical-Literature-

Review_final.pdf (2014), last accessed 2020/11/12.

3. Marques, P.C. (2016) Building sustainable creativity: a conceptual framework. European Journal of Sustainable Development, 5(3), 433-439. 
4. Laužikas, M., Mokšeckienè, R. (2013) The Role of Creativity in Sustainable Business. Entrepreneurship And Sustainability Issues, 1(1), 10-22. Retrieved from https://hal.archives-ouvertes.fr/hal-01694334/document, last accessed 2020/11/13.

5. Cachia, R., Ferrari, A. (2010) Creativity in schools: A Survey of Teachers in Europe. EUR 24585 EN - 2010, European Commission, Joint Research Centre, Institute for Prospective Technological Studies. Retrieved from https://publications.jrc.ec.europa.eu/repository/bitstream/J RC59232/jrc59232.pdf, last accessed 2020/11/12.

6. Lemmetty, S., Glăveanu, V.P., Collin, K. Forsman, P. (2020) (Un)Sustainable Creativity? Different ManagerEmployee Perspectives in the Finnish Technology Sector. Sustainability, 12, 3605.

7. Moraru, G.M. (2016) Creativity in Organizations - an Academic Perspective. 3rd International Multidisciplinary Scientific Conference on Social Sciences and Arts SGEM 2016, Albena, Bulgaria, Book 2, 3, 815-820.

8. Zhou, C., Luo, L. (2012) Group Creativity in Learning Context: Understanding in a Socio-Cultural Framework and Methodology. Creative Education, 3(4), 392-399. Retrieved

from https://www.scirp.org/pdf/CE20120400029_56782232.pdf, last accessed 2020/11/12.

9. Barbieri, J.C., De Vasconcelos, I.F.G., Andreassi, T., De Vasconcelos, F.C. (2010) Innovation and Sustainability:
New Models and Propositions. Revista de Administração de Empresas (RAE), 50(2), 146-154. https://www.scielo.br/pdf/rae/v50n2/en_02.pdf, last accessed 2020/11/13.

10. Millard, J. (2018) How Social Innovation Underpins Sustainable Development. Atlas of Social Innovation, Technische Universität Dortmund ZWE \& Sozialforschungsstelle (Eds. Howaldt, J., Kaletka, C., Schröder, A., Zirngiebl, M.) Part I. The Social Innovation Landscape - Global Trends, 40-43. Retrieved from https://www.socialinnovationatlas.net/fileadmin/PDF/einze ln/01_SI-Landscape_Global_Trends/01_07_How-SIUnderpins-Sustainable-Deve-lopment Millard.pdf, last accessed 2020/11/12.

11. O’Brien, C., Murray, S.E. (2015) Sustainable Wellbeing, Creativity and Innovation. International Journal of Innovation, Creativity and Change, 2(1), 117-124. Retrieved from https://www.ijicc.net/images/Vol2iss1/Sell_May_2015.pdf last accessed 2020/11/13.

12. Popa, D., Moraru, G.M. (2019) Universities as promoters of sustainable development. EDULEARN19 Poceedings, 11th International Conference on Education and New Learning Technologies, Palma de Mallorca (Spain) 44054409. 